\title{
Effect of Organic and Inorganic Nutrient Combinations on Yield and Economics of Black Gram (Vigna mungo L.)
}

\author{
Sandeep Kumar ${ }^{1 *}$, Vomendra Kumar ${ }^{1}$, Thalesh Kumar² and Om Prakash Bhaskar ${ }^{3}$ \\ ${ }^{1}$ Mahamaya College of Agriculture, Indira Gandhi Krishi Vishwavidyalaya, \\ Siyadehi, Dhamtari (C.G.) 493773, India \\ ${ }^{2}$ RNS College of Agriculture, Indira Gandhi Krishi Vishwavidyalaya, Ambagarh Chowki, \\ Rajnandgoan (C.G.) 491665, India \\ ${ }^{3}$ Bhoramdeo College of Agriculture, Indira Gandhi Krishi Vishwavidyalaya, \\ Kawardha (C.G.) 491995, India \\ *Corresponding author
}

\section{Keywords \\ Organic and \\ Inorganic \\ nutrients, Black \\ gram, Economics \\ Article Info \\ Accepted: \\ 26 July 2020 \\ Available Online: \\ 10 August 2020}

\section{A B S T R A C T}

\section{Introduction}

Blackgram (Vigna mungo L.) is one of the important pulse crops grown throughout India. It is rich source of protein (24\%), fat $(1.4 \%)$, carbohydrate $(59.6 \%)$, calcium (154 $\mathrm{mg}$ ), phosphorus (385 $\mathrm{mg})$, iron $(9.1 \mathrm{mg})$, beta carotene $(38 \mathrm{mg})$, thiamine $(0.4 \mathrm{mg})$, riboflavin $(0.37 \mathrm{mg})$ and niacin $(2 \mathrm{mg})$ per $100 \mathrm{~g}$ seeds (Aggarwal et al., 2019). In India, Black gram is grown on 29 lakh ha area with total production of 15.9 lakh tones and productivity of $532 \mathrm{~kg} \mathrm{ha}^{-1}$ (Anonymous, 2015). In Chhattisgarh, it occupies an area of 1.44 lakh ha with the productivity of $320 \mathrm{~kg}$ $\mathrm{ha}^{-1}$ (Anonymous, 2018). It is cultivated mostly on marginal lands in mono/ mixed cropping system without any fertilizers mostly under rainfed condition in India as well as in Chhattisgarh and this is the major fact behind low productivity of the black gram crop. Farmers of Chhattisgarh grow 
blackgram without application of fertilizer or they use less than recommended dose of macro/major and micro/trace nutrients. This imbalanced nutrient supply adversely affects the grain yield of black gram (Vigna mungo L.), soil health, and population of microbes and also the profit of farmers.

By fixing atmospheric nitrogen it play an important role in maintaining soil health but an average yield of crop is far below even from the national average $(532 \mathrm{~kg} / \mathrm{ha})$. The major constraints in maximization the productivity are weed, disease and improper fertilization. Nutrients play important role in exploiting the genetic potential of pulse crop. The significant response to phosphate nutrition by legume crops has been reported by several researchers (Singh and Yadav, 2008).

A large amount of $\mathrm{P}$ gets fixed and only 10$18 \%$ of applied is utilized by the standing crop (Subehia and Sharma 2002). Iron is most important for chlorophyll formation and photosynthesis and iron is also utilized by enzymes to regulate transpiration in plants (Jha et al; 2015). So micro nutrient iron and $\mathrm{Zn}$ play important role when applied with NPK and also helpful in maximize the grain yield of black gram crop. Stevenson, 1967 reported that, application of FYM and vermicompost supplies additional nutrient to the crop and also increase the availability of native nutrient of soil by release of organic acids and other microbial product during the decomposition.

\section{Materials and Methods}

A field experiment was carried out on black gram (var. $T A U-1)$ by sowing of seed $\left(10^{\text {th }}\right.$ march 2020) in planting geometry of $30 \times 5 \mathrm{~cm}$ (RxP) by using the recommended dose of seed $25 \mathrm{~kg} \mathrm{ha}^{-1}$ at instructional farm of Mahamaya College of Agriculture, Siyadehi,
Dhamtari, Chhattisgarh, India during summer season 2018. Siyadehi lies at $20^{\circ} 63^{\prime} \mathrm{N}$ latitude and $81^{\circ} 65$, E longitude with an altitude of 317 meter above mean sea level. The average annual rainfall of the area is $1084 \mathrm{~mm}$ and the amount of precipitation occurs between March to May 2018 is (70.2 $\mathrm{mm}$ ) which is $6.47 \%$ of the total annual precipitation. The average annual temperature is $23.45^{\circ} \mathrm{C}$. The soil of experimental site was inceptisols with $0.42 \%$ organic matter, and $\mathrm{pH}$ of 6.7 and available $\mathrm{N}, \mathrm{P}$ and $\mathrm{K}$ content in the soil was $195.7,8.74$ and $225.5 \mathrm{~kg} \mathrm{ha}^{-1}$, respectively.

The experiment was carried out in complete randomized block design (CRBD) with three replications, assigning 9 treatments viz; (control, 75\% RDF, 100\% RDF, 100\% RDF + $\mathrm{Zn}+\mathrm{Fe}, 50 \% \mathrm{RDF}+50 \% \mathrm{RDN}$ through FYM, FYM $4 \mathrm{t} \mathrm{ha}^{-1}$ (Basal)' vermicompost $2 \mathrm{t}$ $\mathrm{ha}^{-1}$ (Basal), FYM $2 \mathrm{t} \mathrm{ha}^{-1}$ (Basal) + vermicompost 1 tha $^{-1}$ at 25 DAS and vermicompost 1 tha $^{-1}$ (Basal) + vermicompost $1 \mathrm{t} \mathrm{ha}^{-1}$ at $\left.25 \mathrm{DAS}\right)$. The recommended doses of $\mathrm{N}, \mathrm{P}_{2} \mathrm{O}_{5}, \mathrm{~K}_{2} \mathrm{O}, \mathrm{ZnSO}_{4}$, and $\mathrm{FeSO}_{4}$ were 20, 30, 20, 5 and $5 \mathrm{~kg} \mathrm{ha}^{-1}$, respectively. Full dose of nitrogen, phosphorus, potassium, zinc and iron in the form of urea, DAP, MOP, $\mathrm{ZnSO}_{4}$ and $\mathrm{FeSO}_{4}$ were applied basal as per treatments. FYM and vermicompost were incorporated as per treatments. And all other cultural practices were adopted as per need of the crop.

\section{Effect on growth parameter}

The data on growth parameter of black gram (Vigna mungo L.) are presented in table 1. Various growth parameters of black gram were differ with the treatments imposed. The significantly maximum plant height (34.82 $\mathrm{cm})$ at harvest was recorded with treatment $100 \% \mathrm{RDF}+\mathrm{Zn}+\mathrm{Fe}\left(\mathrm{N}: \mathrm{P}: \mathrm{K}-20: 30: 20 \mathrm{~kg} \mathrm{ha}^{-1}\right.$ $+\mathrm{ZnSO}_{4} 5 \mathrm{~kg} \mathrm{ha}^{-1}+\mathrm{FeSO}_{4} 5 \mathrm{~kg} \mathrm{ha}^{-1}$ ), which was at par with treatments $100 \% \mathrm{RDF}, 50 \%$ 
RDF + 50\% RDN through FYM, FYM 4 t ha ${ }^{1}$ (basal) and vermincompost $2 \mathrm{t} \mathrm{ha}^{-1}$ (basal) and lowest $(21.43 \mathrm{~cm})$ at harvest was recorded with treatment control. Similar trend was observed with plant dry matter and leaf area index. Similar trend was observed with test weight. Similar results were observed by Rathore et al., (2010) and Jha et al., (2015).

The data presented in table 1 revealed that, the significant maximum leaf area index (2.34) at harvest ware noticed with treatment $100 \% \mathrm{RDF}+\mathrm{Zn}+\mathrm{Fe}\left(\mathrm{N}: \mathrm{P}: \mathrm{K}-20: 30: 20 \mathrm{~kg} \mathrm{ha}^{-1}\right.$ $\left.+\mathrm{ZnSO}_{4} 5 \mathrm{~kg} \mathrm{ha}^{-1}+\mathrm{FeSO}_{4} 5 \mathrm{~kg} \mathrm{ha}^{-1}\right)$, which was at par with treatment FYM 4t $\mathrm{ha}^{-1}$ followed by treatment 50\% RDF + 50\% RDN through FYM and lowest leaf area index (1.77) was observed in treatment control. Better availability of nutrient might have result in greater leaf area index which ultimately increase the yield of crop by increasing the rate of photosynthesis, dry matter accumulation, increasing energy transformation, root development and by symbiotic biological nitrogen fixation. The similar result observed by Hussain et al., (2011).

\section{Effect on yield and yield attributes}

An analysis of data (Table 1 and 2) show that, yield and yield attributes increased significantly with the application of organic and inorganic sources of nutrients in blackgram over control. The maximum number of pods plant ${ }^{-1}$ (33.64) was significantly highest in treatment $100 \% \mathrm{RDF}+$ $\mathrm{Zn}+\mathrm{Fe}\left(\mathrm{N}: \mathrm{P}: \mathrm{K}-20: 30: 20 \mathrm{~kg} \mathrm{ha}^{-1}+\mathrm{ZnSO}_{4} 5\right.$ $\mathrm{kg} \mathrm{ha}^{-1}+\mathrm{FeSO}_{4} 5 \mathrm{~kg} \mathrm{ha}^{-1}$ ), which was at par with treatment FYM $4 \mathrm{t} \mathrm{ha}^{-1}$ (basal) followed by treatment $100 \% \mathrm{RDF}$ and lowest pods plant $^{-1}$ (18.87) was recorded in treatment control. Significantly the maximum number of seeds pod $^{-1}$ (6.79) was observed in treatment-100\% RDF+ $\mathrm{Zn}+\mathrm{Fe}(\mathrm{N}: \mathrm{P}: \mathrm{K}-$ 20:30:20 kg ha ${ }^{-1}+\mathrm{ZnSO}_{4} 5 \mathrm{~kg} \mathrm{ha}^{-1}+\mathrm{FeSO}_{4} 5$ $\mathrm{kg} \mathrm{ha}^{-1}$ ), which was at par with treatments FYM $4 \mathrm{t} \mathrm{ha}^{-1}$ (basal) and lowest seed pod $^{-1}$ (4.80) was recorded in treatment control.

Table.1 Effect of organic and inorganic nutrient combination on growth and yield attributes of black gram

\begin{tabular}{|c|c|c|c|c|c|c|}
\hline Treatments & $\begin{array}{c}\text { Plant height } \\
\text { (cm) }\end{array}$ & $\begin{array}{c}\text { Dry matter } \\
\text { (g) }\end{array}$ & $\begin{array}{c}\text { Leaf area } \\
\text { index (LAI) }\end{array}$ & $\begin{array}{l}\text { Number of } \\
\text { pods plant }^{-1}\end{array}$ & $\begin{array}{c}\text { Number } \\
\text { of seeds pod }^{-1}\end{array}$ & $\begin{array}{l}\text { Test } \\
\text { weight }(g)\end{array}$ \\
\hline$T_{1}$ : Control & 21.43 & 4.60 & 1.77 & 18.87 & 4.80 & 35.50 \\
\hline $\mathrm{T}_{2}: 75 \% \mathrm{RDF}$ & 30.34 & 6.79 & 2.07 & 24.48 & 5.67 & 36.17 \\
\hline $\mathrm{T}_{3}: 100 \% \mathrm{RDF}$ & 32.28 & 9.87 & 2.23 & 30.80 & 6.28 & 37.36 \\
\hline $\mathrm{T}_{4}: 100 \% \mathrm{RDF}+\mathrm{Zn}+\mathrm{Fe}$ & 34.82 & 10.49 & 2.34 & 33.64 & 6.79 & 42.51 \\
\hline $\begin{aligned} \mathrm{T}_{5}: & \mathbf{5 0 \%} \mathrm{RDF}+\mathbf{5 0 \%} \mathrm{RDN} \\
& \text { through FYM }\end{aligned}$ & 31.51 & 7.80 & 2.25 & 29.73 & 6.35 & 39.17 \\
\hline T $_{6}:$ FYM 4 t ha $^{-1}$ (Basal) & 31.96 & 9.80 & 2.27 & 31.41 & 6.50 & 42.00 \\
\hline $\begin{array}{l}\mathrm{T}_{7}: \\
{ }_{1}^{\text {(Basal) }}\end{array}$ & 31.47 & 7.05 & 2.20 & 24.67 & 5.37 & 36.83 \\
\hline $\begin{array}{c}\text { T}_{8}: \text { FYM } 2 \mathrm{t} \mathrm{ha}^{-1}(\text { Basal) }+ \\
\text { VC } 1 \text { t ha }^{-1} \text { at } 25 \text { DAS }\end{array}$ & 29.43 & 8.56 & 2.01 & 28.48 & 6.01 & 37.04 \\
\hline $\begin{aligned} \mathrm{T}_{9}: & \text { VC 1t ha-1 (Basal) +1 t } \\
& \text { ha }^{-1} \text { at } 25 \text { DAS }\end{aligned}$ & 29.54 & 8.72 & 2.00 & 27.64 & 5.93 & 36.50 \\
\hline $\operatorname{SEm}( \pm)$ & 1.34 & 1.04 & 0.09 & 1.26 & 0.16 & 0.35 \\
\hline $\mathrm{CD}(\mathrm{P}=0.05)$ & 4.08 & 3.16 & 0.27 & 3.83 & 0.49 & 1.06 \\
\hline
\end{tabular}

$\mathrm{RDF}=$ Recommended dose of fertilizer, DAS $=$ Day after sowing, $\mathrm{VC}=$ Vermicompost 
Table.2 Effect of organic and inorganic nutrient combination on yield and economics of black gram

\begin{tabular}{|c|c|c|c|c|c|c|c|}
\hline \multirow[t]{2}{*}{ Treatments } & \multicolumn{3}{|c|}{ Yield (kg ha $\left.{ }^{-1}\right)$} & \multirow{2}{*}{$\begin{array}{c}\text { Harvest } \\
\text { index } \\
(\%)\end{array}$} & \multirow{2}{*}{$\begin{array}{c}\text { Gross } \\
\text { return } \\
\left(₹ \text { ha }^{-1}\right)\end{array}$} & \multirow{2}{*}{$\begin{array}{c}\text { Net } \\
\text { return } \\
\left(₹ \text { ha }^{-1}\right)\end{array}$} & \multirow{2}{*}{$\begin{array}{l}\text { B:C } \\
\text { ratio }\end{array}$} \\
\hline & Seed & straw & biological & & & & \\
\hline $\mathrm{T}_{1}:$ Control & 427.96 & 1073.49 & 1501.45 & 28.51 & 23965.57 & 11925.57 & 1.99 \\
\hline $\mathrm{T}_{2}: 75 \% \mathrm{RDF}$ & 638.20 & 1556.86 & 2195.06 & 29.09 & 35739.01 & 19319.01 & 2.18 \\
\hline $\mathrm{T}_{3}: 100 \% \mathrm{RDF}$ & 796.97 & 1760.39 & 2557.35 & 31.16 & 44630.13 & 28243.47 & 2.72 \\
\hline $\mathrm{T}_{4}: 100 \% \mathrm{RDF}+\mathrm{Zn}+\mathrm{Fe}$ & 857.24 & 1851.44 & 2708.68 & 31.65 & 48005.25 & 31205.25 & 2.86 \\
\hline 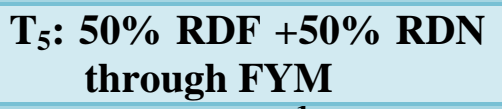 & 752.32 & 1733.00 & 2485.32 & 30.25 & 42129.73 & 26036.40 & 2.62 \\
\hline $\mathrm{T}_{6}:$ FYM $4 \mathrm{t} \mathrm{ha}^{-1}$ (Basal) & 842.70 & 1831.34 & 2674.05 & 31.49 & 47191.39 & 30541.39 & 2.83 \\
\hline 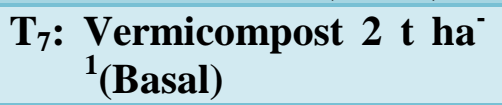 & 710.51 & 1515.71 & 2226.22 & 31.91 & 39788.75 & 21888.75 & 2.22 \\
\hline $\begin{array}{r}\text { T}_{8}: \text { FYM } 2 \mathrm{t} \mathrm{ha}^{-1}(\text { Basal })+ \\
\text { VC } 1 \mathrm{t} \mathrm{ha}^{-1} \text { at } 25 \text { DAS }\end{array}$ & 745.14 & 1728.32 & 2473.46 & 30.11 & 41727.65 & 23527.65 & 2.29 \\
\hline $\begin{array}{c}\text { T9: }_{9} \text { VC 1t ha-1 (Basal) }+1 \\
\text { t ha }^{-1} \text { at } 25 \text { DAS }\end{array}$ & 708.35 & 1509.71 & 2218.05 & 31.91 & 39667.41 & 21150.75 & 2.15 \\
\hline $\operatorname{SEm}( \pm)$ & 25.52 & 19.70 & 32.60 & 0.78 & 1429.29 & 1382.81 & 0.07 \\
\hline $\mathrm{CD}(\mathrm{P}=0.05)$ & 77.17 & 59.57 & 98.58 & NS & 4321.90 & 4181.36 & 0.23 \\
\hline
\end{tabular}

$\mathrm{RDF}=$ Recommended dose of fertilizer, DAS $=$ Day after sowing, $\mathrm{VC}=$ Vermicompost

Assessment of effect of split dose of vermicompost show that split application of vermicompost $1 \mathrm{t} \mathrm{ha}^{-1}$ at $25 \mathrm{DAS}$ along with FYM $2 \mathrm{t} \mathrm{ha}^{-1}$ (Basal) recorded a significant increase yield attributes of black gram over vermicompost $1 \mathrm{t} \mathrm{ha}^{-1}$ (Basal)+vermicompost $1 \mathrm{t} \mathrm{ha}^{-1}$ at 25 DAS and control, respectively. Similarly significantly maximum grain yield $\left(857.24 \mathrm{~kg} \mathrm{ha}^{-1}\right)$, straw yield (1851.44 kg ha $\left.{ }^{-1}\right)$ and biological yield (2708.68 $\left.\mathrm{kg} \mathrm{ha}^{-1}\right)$ recorded with the treatment $100 \% \mathrm{RDF}+\mathrm{Zn}$ $+\mathrm{Fe}\left(\mathrm{N}: \mathrm{P}: \mathrm{K}-20: 30: 20 \mathrm{~kg} \mathrm{ha}^{-1}+\mathrm{ZnSO}_{4} 5 \mathrm{~kg}\right.$ $\mathrm{ha}^{-1}+\mathrm{FeSO}_{4} 5 \mathrm{~kg} \mathrm{ha}^{-1}$ ), which was at par with treatment FYM $4 \mathrm{t} \mathrm{ha}^{-1}$ (basal) followed by $100 \%$ RDF. The maximum harvest index $(31.91 \%)$ was recorded under treatment vermicompost $2 \mathrm{t} \mathrm{ha}^{-1}$ (basal), it might be due to less vegetative growth of plants which ultimate produce lower biological yield which increase the percentage of harvest index.

Application of $100 \% \mathrm{RDF}+\mathrm{Zn}+\mathrm{Fe}$ significantly enhance seed yield by 21.9 and
6.10 per cent over $75 \%$ RDF and $100 \%$ RDF, respectively. Further, assessment of effect of split dose of vermicompost show that split application of vermicompost $1 \mathrm{t} \mathrm{ha}^{-1}$ at 25 DAS along with FYM $2 \mathrm{t} \mathrm{ha}^{-1}$ as basal recorded a significant increase of 3.68 per cent in seed yield over vermicompost $1 \mathrm{t} \mathrm{ha}^{-1}$ (Basal) + vermicompost $1 \mathrm{tha}^{-1}$ at 25 DAS.

The combination of $\mathrm{NPK}+\mathrm{Zn}+\mathrm{Fe}$ enhance the availability of macro and micro nutrients to black gram crop, which increase the early root development and cell multiplication ratio which enhance the absorption of other nutrients from the deeper layer of soil ultimately resulting the higher plant growth attributes, which increase the dry matter accumulation, finally which enhanced yield attributes and yield of crop which might be due to greater availability of nutrients which was easily absorbed by the crop which significantly increase the rate of photosynthesis. The translocation and 
accumulation of photosynthates in the economic sinks resulted in increased seed, straw and biological yields. The incorporation of $\mathrm{Zn}$ and Fe with $100 \%$ RDF significantly enhance the seed, straw and biological yield of black gram crop.

The absorption of $\mathrm{Zn}$ and $\mathrm{Fe}$ might be increase the rate of nitrogen metabolism, biosynthesis of hormones and rate of photosynthesis which ultimate increase the yield of crop. Similar findings are also reported by Athokpam et al., (2009) and Jha et al., (2015).

\section{Economics of the treatments}

The data presented in table 2 revealed that, significantly higher gross return (48005.25 ₹ $\mathrm{ha}^{-1}$ ) was recorded in treatment $100 \% \mathrm{RDF}+$ $\mathrm{Zn}+\mathrm{Fe}\left(\mathrm{N}: \mathrm{P}: \mathrm{K}-20: 30: 20 \mathrm{~kg} \mathrm{ha}^{-1}+\mathrm{ZnSO}_{4} 5\right.$ $\mathrm{kg} \mathrm{ha}^{-1}+\mathrm{FeSO}_{4} 5 \mathrm{~kg} \mathrm{ha}^{-1}$ ) which was at par with $100 \%$ RDF (44630.13 ₹ $\mathrm{ha}^{-1}$ ) and FYM $4 \mathrm{t} \mathrm{ha}^{-1}$ (basal) (47191.39 ₹ $\mathrm{ha}^{-1}$ ) over rest of the treatments and control.

The maximum net return (31205.25 ₹ $\left.\mathrm{ha}^{-1}\right)$ which was at par with which was at par with $100 \%$ RDF (28243.47 ₹ $\mathrm{ha}^{-1}$ ) and FYM $4 \mathrm{t}$ $\mathrm{ha}^{-1}$ (basal) (30541.39 ₹ $\mathrm{ha}^{-1}$ ) over rest of the treatments. The maximum B: $\mathrm{C}$ ratio (2.86) was recorded in treatment $100 \% \mathrm{RDF}+\mathrm{Zn}$ $+\mathrm{Fe}\left(\mathrm{N}: \mathrm{P}: \mathrm{K}-20: 30: 20 \mathrm{~kg} \mathrm{ha}^{-1}+\mathrm{ZnSO}_{4} 5 \mathrm{~kg}\right.$ $\mathrm{ha}^{-1}+\mathrm{FeSO}_{4} 5 \mathrm{~kg} \mathrm{ha}^{-1}$ ) which was at par with FYM $4 \mathrm{t} \mathrm{ha}^{-1}$ (basal) (2.83) over rest of the treatments and control. on the other hand, application of $100 \% \mathrm{RDF}+\mathrm{Zn}+\mathrm{Fe}(\mathrm{N}: \mathrm{P}: \mathrm{K}-$ 20:30:20 kg ha ${ }^{-1}+\mathrm{ZnSO}_{4} 5 \mathrm{~kg} \mathrm{ha}^{-1}+\mathrm{FeSO}_{4} 5$ $\mathrm{kg} \mathrm{ha} \mathrm{h}^{-1}$ ) considerably enhanced the plant growth, higher dry matter production and nutrients uptake compared to control and resulted in significant increase in pods plant ${ }^{-1}$, and seed yield of black gram (Vigna mungo L.) crop. Present study is closely related to findings of Jha et al., (2015) and Kumawat et al., (2013).
In conclusion, it is accomplished from that investigation the application of recommended dose of fertilizer (100\% NPK of RDF) @ 20:30:20 and FYM @ $4 \mathrm{t} \mathrm{ha}^{-1}$ recorded better seed yield 796.97 and $842.70 \mathrm{~kg} \mathrm{ha}^{-1}$ of black gram crop respectively. The maximum seed yield $\left(857.24 \mathrm{~kg} \mathrm{ha}{ }^{-1}\right)$ and net return (31205.25 ₹ $\mathrm{ha}^{-1}$ ) was obtained in the treatment consisting the basal application of $\mathrm{Zn}$ and $\mathrm{Fe}$ along with $100 \%$ nitrogen, phosphorus and potash (Recommended dose of fertilizer). The incorporation of $\mathrm{ZnSO}_{4}$ and $\mathrm{FeSO}_{4}$ as basal @ $5 \mathrm{~kg} \mathrm{ha}^{-1}$ along with $100 \%$ NPK of RDF prone superior to application of $100 \%$ NPK of RDF in terms of growth and yield parameters of black gram crop.

\section{References}

Aggarwal, S.K., Mali, B. L., Trivedi, A., Bunker, R.N., Rajput, L.S., Kumar, S. and Tripathi, A. (2019). Host Plant Resistance in Different Black Gram Cultivars against Anthracnose. Int.J.Curr.Microbiol.App.Sci. $\quad$ 8(03): 571-575

Anonymous. (2018) Area and productivity of different crops in Chhattisgarh. Directorate of agriculture, government of Chhattisgarh, Raipur. 6-8.

Anonymous. 2015. Area, production and productivity of black gram. Economic Survey of Maharashtra.

Athokpam, H. S., Chongtham, N., Singh, R. K. K., Singh, N. G. and Singh, N. B. (2009). Effect of nitrogen, phosphorus and potassium on growth, yield and nutrient uptake by blackgram (Vigna mungo L.). Environment and Ecology, 27: 682-684.

Hussain, N., Mehdi, M. and Kant, R. H. (2011). Response of Nitrogen and Phosphorus on Growth and Yield Attributes of Blackgram (Vigna mungo). Research Journal of Agricultural Sciences, 2: 334-336. 
Jha, D.P., Sharma, S.K. and Amrawat, T. (2009). Effect of organic and inorganic sources of nutrients on yield and economics of black gram (Vigna mungo L.) grown during kharif. Agric.Sci.Digest., 35(2): 224-228.

Kumawat, P. K.,Tiwari, R. C., Golada, S. L., Godara, A. S., Garhwal, R. S. and Choudhary, R. (2013). Effect of Phosphorus sources, levels and Biofertilizers on Yield attributes, Yield and Economics of Blackgram (Phaseolus Mungo L.). Legume Research, 36: 70-73.

Rathore, R.S., Singh, R.P. and Nawange, D.D. (2010). Effect of land configuration, seed rates and fertilizer doses on growth and yield of blackgram
[Vigna mungo (L.) hepper]. Legume Research, 33: 274-278.

Singh, R.S. and Yadav M.K. (2008). Effect of phosphorus and biofertilizers on growth, yield and nutrient uptake of long duration Pigeonpea under rainfed condition. Journal of Food Legumes 21: 46-48.

Stevenson FJ. (1967). Organic acids in soil. In: Soil Biochemistry Vol I(A.D. MacLaren and G.H. Perterson, Ed) Marcel Dekker New York.pp. 119.

Subehia, S.K. and Sharma, S.P. (2002). Nutrient budgeting in a long-term fertilizers experiment. In transactions, 17th world congress of soil science held at Bangkok in Thailand from 14-21st August, 2002. 33: 1-8.

\section{How to cite this article:}

Sandeep Kumar, Vomendra Kumar, Thalesh Kumar and Om Prakash Bhaskar. 2020. Effect of Organic and Inorganic Nutrient Combinations on Yield and Economics of Black Gram (Vigna mungo L.). Int.J.Curr.Microbiol.App.Sci. 9(08): 3366-3371. doi: https://doi.org/10.20546/ijcmas.2020.908.388 